\title{
First co-expression of a lipase and its specific foldase obtained by metagenomics
}

\author{
Viviane Paula Martini ${ }^{1,2}$, Arnaldo Glogauer ${ }^{3,4}$, Marcelo Müller-Santos ${ }^{3}$, Jorge lulek ${ }^{5}$,Emanuel Maltempi de Souza ${ }^{3}$, \\ David Alexander Mitchell ${ }^{3}$, Fabio Oliveira Pedrosa ${ }^{3}$ and Nadia Krieger ${ }^{1 *}$
}

\begin{abstract}
Background: Metagenomics is a useful tool in the search for new lipases that might have characteristics that make them suitable for application in biocatalysis. This paper reports the cloning, co-expression, purification and characterization of a new lipase, denominated LipG9, and its specific foldase, LifG9, from a metagenomic library derived from a fat-contaminated soil.

Results: Within the metagenomic library, the gene lipg9 was cloned jointly with the gene of the foldase, lifg9. LipG9 and LifG9 have 96\% and 84\% identity, respectively, with the corresponding proteins of Aeromonas veronii B565. LipG9 and LifG9 were co-expressed, both in N-truncated form, in Escherichia coli BL21(DE3), using the vectors pET28a(+) and pT7-7, respectively, and then purified by affinity chromatography using a $\mathrm{Ni}^{2+}$ column (HiTrap Chelating HP). The purified enzyme eluted from the column complexed with its foldase. The molecular masses of the N-truncated proteins were $32 \mathrm{kDa}$ for LipG9, including the N-terminal His-tag with 6 residues, and 23 kDa for LifG9, which did not have a His-tag. The biochemical and kinetic characteristics of the purified lipase-foldase preparation were investigated. This preparation was active and stable over a wide range of $\mathrm{pH}$ values (6.5-9.5) and temperatures $\left(10-40^{\circ} \mathrm{C}\right)$, with the highest specific activity, of $1500 \mathrm{U} \mathrm{mg}^{-1}$, being obtained at $\mathrm{pH} 7.5$ at $30^{\circ} \mathrm{C}$. It also had high specific activities against tributyrin, tricaprylin and triolein, with values of 1852, 1566 and $817 \mathrm{U} \mathrm{mg}^{-1}$, respectively. A phylogenetic analysis placed LipG9 in the lipase subfamily I.1. A comparison of the sequence of LipG9 with those of other bacterial lipases in the Protein Data Bank showed that LipG9 contains not only the classic catalytic triad $\left(\mathrm{Ser}^{103}, \mathrm{Asp}^{250}, \mathrm{His}^{272}\right)$, with the catalytic Ser occurring within a conserved pentapeptide, Gly-His-Ser-His-Gly, but also a conserved disulfide bridge and a conserved calcium binding site. The homology-modeled structure presents a canonical $\alpha / \beta$ hydrolase folding type I.
\end{abstract}

Conclusions: This paper is the first to report the successful co-expression of a lipase and its associated foldase from a metagenomic library. The high activity and stability of Lip-LifG9 suggest that it has a good potential for use in biocatalysis.

Keywords: Lipases, Metagenomics, Biocatalysis, Lipase-foldase co-expression

\section{Background}

Lipases can be used as biocatalysts in the synthesis of value-added esters for use in the cosmetic $[1,2]$ and aroma industries [3-5], in the enzymatic synthesis of biodiesel [6-12], in the modification of fats and oils [13] and to carry out stereospecific reactions in the synthesis of pharmaceuticals and other high-value compounds [14-16]. In many of these applications water is not the solvent, with the reaction being carried out in hydrophobic solvents, although hydrophilic solvents such as methanol or ethanol

\footnotetext{
* Correspondence: nkrieger@ufpr.br

1Departamento de Química, Universidade Federal do Paraná, Cx. P. 19081

Centro Politécnico, Curitiba 81531-980, Paraná, Brazil

Full list of author information is available at the end of the article
}

may be present as substrates $[17,18]$. These solvents can negatively affect activity and cause high rates of denaturation. This has prompted researchers to search for new esterases and lipases that have high activity and stability in organic solvents. To date, this has mostly been done through traditional techniques of isolation and cultivation of microorganisms, but there are several recent reports involving the metagenomic approach, in which genes have been isolated directly from environments such as bovine rumen microflora [19], mud and sediment-rich water in thermal environments [20,21], oil-contaminated soils [14,22-25], soils and compost [26,27], deep-sea sediments [28-31], arctic sediments [32,33], leachates [34] and soils from other ecosystems [22,35-41]. 
The metagenomic approach involves heterologous expression and a key issue in producing lipases through heterologous expression is to obtain an active enzyme. In some cases, the correct folding of the lipase requires the presence of a specific foldase. This is the case, for example, with the lipases of the gram-negative bacteria Pseudomonas and Burkholderia, which belong to lipase subfamilies I.1 and I.2 $[42,43]$.

Studies of co-expression of lipases and their foldases are still scarce. There are two possible strategies for obtaining foldase-assisted folding. Firstly, in vitro folding can be used, in which the foldase is produced separately and added to a crude or purified extract. Some success has been obtained using this approach [44-47]. Secondly, in vivo folding can be used, in which traditional molecular biology techniques are used to co-express the foldase with the lipase [46]. However, in the case of the metagenomic approach, the co-expression is more complicated, since it requires the cloning of both the lipase and foldase on the same DNA fragment. This has not previously been reported in the literature.

In our work, we describe, for the first time, the coexpression, in Escherichia coli, of a new metagenomic lipase, LipG9, with its specific foldase, its purification and biochemical and kinetic characterization.

\section{Results}

\section{Library, activity screening, sequencing and preliminary} sequence analysis

In previous work, Glogauer et al. [24] constructed a metagenomic library, consisting of 500000 clones, from a sample of fat-contaminated soil from an anaerobic lagoon of the wastewater treatment plant of a meat packing and dairy industry located in the state of Paraná, Brazil. Of these clones, 127 showed activity against tricaprylin and 32 showed activity against triolein. In the present work, one of the clones with activity against triolein, pCC2FOS-lipg9-lifg9, was selected for expression and characterization.

Sequencing of pCC2FOS-lipg9-lifg9 identified a 2708 bp contig, which aligned to Aeromonas veronii lactonizing lipase with $47 \%$ coverage and 99\% identity. Within the contig, a 921 bp lipase gene (lipg9) and a 723 bp foldase gene (lifg9), with $96 \%$ and $84 \%$ identity, respectively, with the corresponding genes from Aeromonas veronii B565 [GenBank:10486164, GenBank:10486163], were identified. The TMHMM server [48] identified a putative transmembrane $\alpha$-helix for the foldase, while SignalP [49] identified both a signal peptide and a putative cleavage site for the lipase. These results suggest that LipG9 is secreted using the Sec mechanism, as reported for other bacterial lipases, such as those from Pseudomonas spp. [42,50,51], Burkholderia spp. [42,52,53] and Aeromonas spp. [54].

\section{Cloning strategy, co-expression, purification and mass spectrometry analysis}

On the basis of the sequence results, primers were designed for the genes lipG9 and lifG9, both for the sequences of the entire genes and for sequences in which, respectively, the first 75 nucleotides (corresponding to 25 amino acids) and 99 nucleotides (corresponding to 33 amino acids) were deleted. These $\mathrm{N}$-truncated sequences simulated the predicted in vivo Sec mechanism of secretion for LipG9. In the expression studies undertaken with these constructs, no lipolytic activity was detected in the culture medium when LipG9 was expressed alone in $E$. coli BL21(DE3), nor when LipG9 was cloned and coexpressed with its foldase, with LipG9 having a His-tag on the C-terminal, this being true for both the entire and the $\mathrm{N}$-truncated constructs (Table 1). On the other hand, when LipG9 and LifG9 were co-expressed, with LipG9 having a His-tag on its N-terminal, lipolytic activity was detected in the medium for both the entire and the $\mathrm{N}$ truncated constructs (Table 1), which gave specific activities against tricaprylin of up to $12 \mathrm{U} \mathrm{mg}^{-1}$. The construct in which the N-terminals of both the lipase and its foldase were deleted was selected for the overexpression and purification of the complex Lip-LifG9.

During purification, the lipase and foldase were co-eluted from the affinity column when imidazol was in the concentration range of $0.208 \mathrm{~mol} \mathrm{~L}^{-1}$ to $0.280 \mathrm{~mol} \mathrm{~L}^{-1}$. Since only the lipase had a His-tag, the foldase must have been complexed to the lipase that bound to the support. The two bands on the SDS-PAGE gel (lane 1, Figure 1) correspond to the lipase and the foldase, for which ProtParam [48] had predicted theoretical molecular masses of $32 \mathrm{kDa}$ and $24 \mathrm{kDa}$, respectively. The migration of the lipase was consistent with its theoretical molecular mass. However, the migration of the foldase was aberrant, giving a higher than expected apparent molecular mass, $31 \mathrm{kDa}$. According to the densitometry analysis, the bands in the SDS-PAGE were 95\% pure. As the bands gave approximately the same density, it can be deduced that the complex is eluted from the affinity column in a 1:1 proportion of LipG9 and LifG9.

The sequences obtained through mass spectrometry (MALDI-TOF) confirmed that LipG9 and LifG9 were Ntruncated. The fragment masses in the mass spectra were compared to theoretical masses predicted by in silico peptide cleavage using ProteinProspector [55], giving sequence coverages of $25 \%$ for the lipase and $39 \%$ for the foldase (data not shown). The sequence coverages and the fragment masses of both LipG9 and LifG9 confirmed the identity of the purified enzyme complex.

\section{Protein sequence and protein 3D structure model analyses}

The phylogenetic analysis of LipG9 indicates that it belongs to lipase subfamily I.1 (Figure 2), the same subfamily 
Table 1 Co-expression assays and lipase activity of the constructs

\begin{tabular}{|c|c|c|c|c|c|}
\hline Construct & Vectors & Lipase (LipG9) & Location of His-Tag in LipG9 & Foldase (LifG9) & Activity $\left(\mathrm{U} \mathrm{mg}^{-1}\right)^{*}$ \\
\hline \# 1 & $\mathrm{pET} 29 \mathrm{~b}(+)$ & Entire & C-terminal & - & - \\
\hline \# 2 & pET29b(+) & $\mathrm{N}$-truncated & C-terminal & - & - \\
\hline \# 3 & pET28a $(+)$ & Entire & $\mathrm{N}$-terminal & - & - \\
\hline \# 4 & pET28a(+) & $\mathrm{N}$-truncated & N-terminal & - & - \\
\hline \# 5 & pT7-7 & - & - & Entire & - \\
\hline \# 6 & pT7-7 & - & - & N-truncated & - \\
\hline \# 1-5 & pET29b(+) and pT7-7 & Entire & C-terminal & Entire & - \\
\hline \# 1-6 & pET29b(+) and pT7-7 & Entire & C-terminal & N-truncated & - \\
\hline \# 2-5 & pET29b(+) and pT7-7 & $\mathrm{N}$-truncated & C-terminal & Entire & - \\
\hline \# 2-6 & pET29b(+) and pT7-7 & $\mathrm{N}$-truncated & C-terminal & N-truncated & - \\
\hline \# 3-5 & pET28a(+) and pT7-7 & Entire & N-terminal & Entire & $12 \pm 1$ \\
\hline \# 3-6 & pET28a(+) and pT7-7 & Entire & N-terminal & $\mathrm{N}$-truncated & $2 \pm 0$ \\
\hline \# 4-5 & pET28a(+) and pT7-7 & $\mathrm{N}$-truncated & $\mathrm{N}$-terminal & Entire & $1 \pm 0$ \\
\hline \# 4-6 & pET28a(+) and pT7-7 & $\mathrm{N}$-truncated & $\mathrm{N}$-terminal & $\mathrm{N}$-truncated & $11 \pm 1$ \\
\hline
\end{tabular}

*The activity was determined by the titrimetric method with tricaprylin as the substrate, using a pHStat at $\mathrm{pH} 7.5$ and $30^{\circ} \mathrm{C}$. Results are expressed as the average of triplicates assays \pm the standard error of the mean.

as that of the lipases from Pseudomonas aeruginosa [GenBank:ACA49549.1], Aeromonas hydrophila [GenBank:ABK 37008.1] and Aeromonas veronii [GenBank:AEB48282.1]. Of these three lipases, it has highest identity, $96 \%$, with the last one.

The LipG9 sequence was aligned with the sequences of lipases that are available in the PDB (Protein Data Bank) [57]. LipG9 has sequence identities of $72 \%$ with the lipase from Pseudomonas aeruginosa (PDB:1EX9), 54\% with the lipase from Burkholderia cepacia (PDB:1OIL) and 51\% with the lipase from Burkholderia glumae (PDB:2ES4). Figure 3 shows the alignment and the estimated secondary structures. These structures were used as templates for the structural homology modeling.

The N-termini of LipG9 and of the structures from the PDB were not aligned due to the fact that the PDB sequences do not show ordered crystal structures for the $\mathrm{N}$-terminal regions. The alignment suggests that LipG9 possesses the conserved sequential pentapeptide Gly-XaaSer-Xaa-Gly, which is typical of lipases of subfamily I.1 [43], with both Xaa corresponding to His residues, centered on $\mathrm{Ser}^{103}$ (Figure 3). The other two residues of the catalytic triad were identified as $\mathrm{Asp}^{250}$ and $\mathrm{His}^{272}$. These two residues are in the $\mathrm{C}$-terminal region and they are also part of the $\alpha / \beta$ hydrolase fold that is typical of lipases.

The alignment of LipG9 with PDB structures also suggests that $\mathrm{Asp}^{232}, \mathrm{Asp}^{274}, \mathrm{Gln}^{278}$ and $\mathrm{Ile}^{282}$ form a calcium binding pocket, which is noteworthy, since lipases that have a bound calcium usually have higher activities and stability than those that do not [59]. LipG9 also contains two cysteine residues $\left(\mathrm{Cys}^{205}\right.$ and $\mathrm{Cys}^{256}$ ) that are predicted to form a disulfide bridge, analogous to that which occurs in the lipases of $A$. hydrophila, A. salmonicida and other lipases used as templates in the alignment (Figure 3). The presence of the disulfide bridge suggests that LipG9 may be extracellular in the original microorganism [60].

The final LipG9 structural homology models were built with 286 amino acids and the calcium ion. The consistency of the proposed models was extensively checked. The model with the lowest normalized DOPE score $(-1.064)$ and a GA341 score of 1.000 (which indicated a correct fold) was chosen for later analyses. This DOPE score is close to those of the templates $(-1.816,-1.507$ and -1.193 for 2ES4, 1EX9 and 1OIL, respectively). The program PROCHECK identified three Ramachandran outliers; two of the outlying residues occur in loops and have conformations close to the limits of allowed regions on the Ramachandran plot. The other outlier is $\mathrm{Ser}^{103}$, which is predicted to have the same conformation as the corresponding Ser residues in the templates. The domain analysis carried out using the Pfam database showed that LipG9 probably has a canonical $\alpha / \beta$ hydrolase folding type I, between residues $\mathrm{Gly}^{23}$ and Lys $^{246}$.

To explore the structural characteristics of LipG9 further, its model was superimposed on the structures of the three lipases used as templates. As shown in Figure 4, LipG9 and these three lipases have very similar conformations. This structural modeling confirmed key features that were predicted above for LipG9 by other methods, including the canonical $\alpha / \beta$ hydrolase fold (Figure 4 , parts a and b), the calcium binding pocket (Figure 4, parts $\mathrm{c}$ and e) and the disulfide bridge. With respect to the calcium binding pocket, the model confirms that the carboxylate groups of $\mathrm{Asp}^{232}$ and $\mathrm{Asp}^{274}$ are in the correct positions to coordinate the calcium ion adequately (Figure $4 \mathrm{c}$ ). With respect to the disulfide bridge, the model confirms that $\mathrm{Cys}^{205}$ and $\mathrm{Cys}^{256}$ 


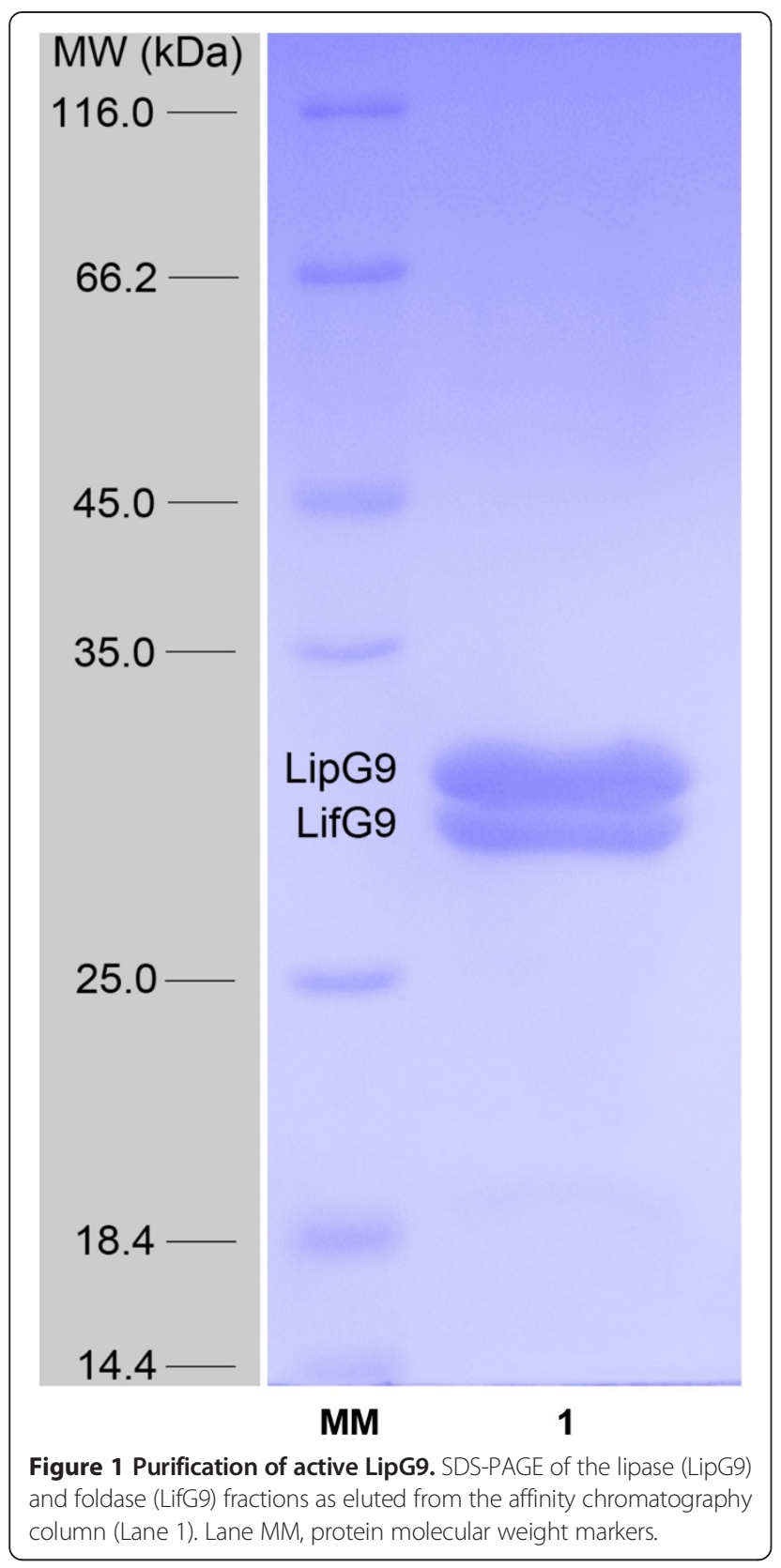

are adequately positioned to form this bridge. Additionally, the modeled LipG9 structure shows the lid subdomain, which is composed of four $\alpha$-helices, in an open conformation that is similar to the open-lid conformations of the lipase structures of $B$. cepacia (1OIL) and P. aeruginosa (1EX9) (Figure 4, parts f and g).

\section{Hydrolytic activity of Lip-LifG9 against triacylglycerols}

The activity of the purified preparation of LipG9 and LifG9 was studied. This preparation will be referred to from this point as Lip-LifG9. Although the lipase and foldase were eluted from the affinity column in complexed form and may have remained as a complex throughout this part of the work, it should be noted that we did not undertake any studies to confirm that the two proteins in fact remained bound in a complex.

The highest specific activity of Lip-LifG9 was against tributyrin $\left(1852 \mathrm{U} \mathrm{mg}^{-1}\right)$. The specific activity decreased with increasing length of the carbon chain, from $1566 \mathrm{U}$ $\mathrm{mg}^{-1}$ for tricaprylin to $817 \mathrm{U} \mathrm{mg}^{-1}$ for triolein (Figure 5). Specific activities were between 870 and $1190 \mathrm{U} \mathrm{mg}^{-1}$ for all commercial oils tested, except for castor oil, with which Lip-LifG9 had a specific activity of only 205 $\mathrm{U} \mathrm{mg}^{-1}$, probably because of the unusual hydroxyl group on the twelfth carbon of ricinoleic acid.

\section{Effect of temperature on Lip-LifG9 activity and stability}

The highest specific activity of Lip-LifG9 for the hydrolysis of tricaprylin was obtained at $30^{\circ} \mathrm{C}(1566 \pm 101$ $\left.\mathrm{U} \mathrm{mg}{ }^{-1}\right)$. At $50^{\circ} \mathrm{C}$, its activity was only half this value and at $60^{\circ} \mathrm{C}$ it was only $30 \%$ of this value (Figure 6). In stability studies involving previous incubation of LipLifG9 for $1.5 \mathrm{~h}$ at $10-40^{\circ} \mathrm{C}$ without substrate, residual activities of around $90 \%$ or better were obtained. At the higher temperatures of $50^{\circ} \mathrm{C}$ and $60^{\circ} \mathrm{C}$, the residual activities were around $70 \%$ and $30 \%$, respectively (Figure 6).

\section{Effect of pH on Lip-LifG9 activity and stability}

Lip-LifG9 had high specific activities (around $1500 \mathrm{U}$ $\mathrm{mg}^{-1}$ ) from $\mathrm{pH} 6.5$ to 10.5 (Figure 7 ). In the stability study, residual activities were highest after incubation at $\mathrm{pH}$ values from 5.5 to 9.5. The composition of the buffer affected stability: Lip-LifG9 was more stable at $\mathrm{pH} 5.5$ when incubated in 2-(N-morpholino)ethanesulfonic (MES) buffer (100\% residual activity) than in citratephosphate buffer (50\% residual activity).

\section{Stability of Lip-LifG9 in organic solvents}

Lip-LifG9 was incubated, at $30^{\circ} \mathrm{C}$ for $1.5 \mathrm{~h}$, in different concentrations of various organic solvents. With the exception of DMSO, the residual activity of Lip-LifG9 after incubation decreased with increasing solvent concentration (Figure 8). Even so, in the case of acetone, isopropanol and ethanol, Lip-LifG9 presented residual activities of over $50 \%$ after incubation in concentrations from 50 to $75 \%$. Such stability is desirable for biocatalytic applications, since these solvents are used in many organic syntheses that require hydrophilic solvents. With DMSO, Lip-LifG9 had over $85 \%$ residual activity for all studied concentrations.

\section{Discussion}

\section{The importance of the co-expression strategy used for} LipG9-LifG9

Researchers have faced difficulties with the expression of active enzymes in heterologous systems when prospecting for new enzymes, with the formation of inclusion bodies 


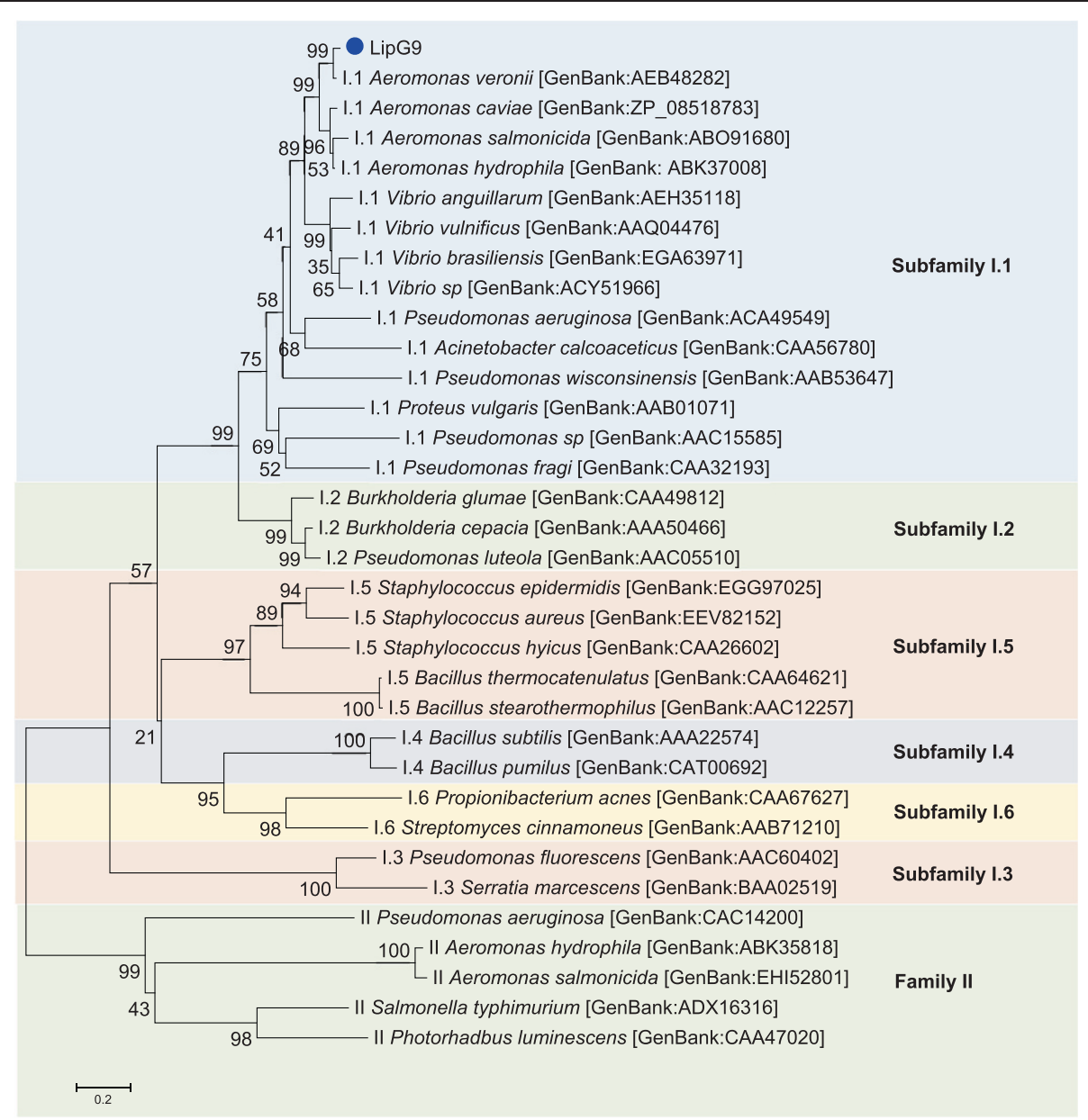

Figure 2 Phylogenetic analysis of LipG9 and closely related proteins. The enzymes most similar to LipG9 are from Aeromonas spp. and Vibrio spp. LipG9 is a member of subfamily I.1 [43]. Except for LipG9, the protein sequences were retrieved from GenBank (NCBI). The phylogenetic tree was generated using MEGA 6 [56]. The scale represents the number of amino acid substitutions per site.

being one of the most frequently reported obstacles [46,61-65]. Obtaining active enzymes has the potential to be even more problematic when the enzyme requires a foldase for proper folding, such as is commonly the case with lipases $[42,66]$. In the current work, we used a simple and effective in vivo folding strategy, in which the genes of a lipase and a foldase, obtained through the metagenomic approach, were cloned in different plasmids and inserted into a single heterologous host, E. coli BL21(DE3). Through this approach, we obtained much higher specific activities than did Madan and Mishra [67], who used a similar approach to co-express a non-metagenomic lipase and its corresponding foldase, from P. aeruginosa B2264, in E. coli BL21 (DE3). They reported an activity of $225 \mathrm{U} \mathrm{mg}^{-1}$, using $p$-nitrophenyl palmitate as the substrate. We produced a lipase with higher specific activities, not only against purified triacylglycerols (1560 $\mathrm{U} \mathrm{mg}^{-1}$ and $817 \mathrm{U} \mathrm{mg}^{-1}$ for tricaprylin and triolein, respectively) and but also against commercial oils, such as canola, corn, olive and palm oils (all above $1000 \mathrm{U} \mathrm{mg}^{-1}$ ).
The co-expression strategy that we used has the advantage of being simpler than in vitro strategies. For instance, Pauwels et al. [52,68] expressed the lipase of B. glumae and its foldase separately, in homologous and heterologous hosts, respectively, and then combined them during the protein purification step, in which the $\mathrm{Ni}^{2+}$ affinity column was loaded with separate extracts from each protein. Additionally, in vitro folding is not always particularly effective. Hobson et al. [47] showed this by expressing the lipase from P. cepacia DSM 3959 in E. coli, denaturing it with urea and then refolding it by dialysis in the presence of its foldase, which was also expressed separately in $E$. coli [47]. Only 5 to $10 \%$ of the initial activity of the enzyme was regained after refolding. However, it is not impossible to obtain high specific activities using in vitro folding, as shown by Traub et al. [45]. They prepared E. coli cell extracts containing denatured $\mathrm{N}$-truncated lipases from Pseudomonas sp. and Chromobacterium viscosum. After adding the respective foldases, they obtained specific activities against triolein of $3900 \mathrm{U} \mathrm{mg}^{-1}$ for the lipase of 


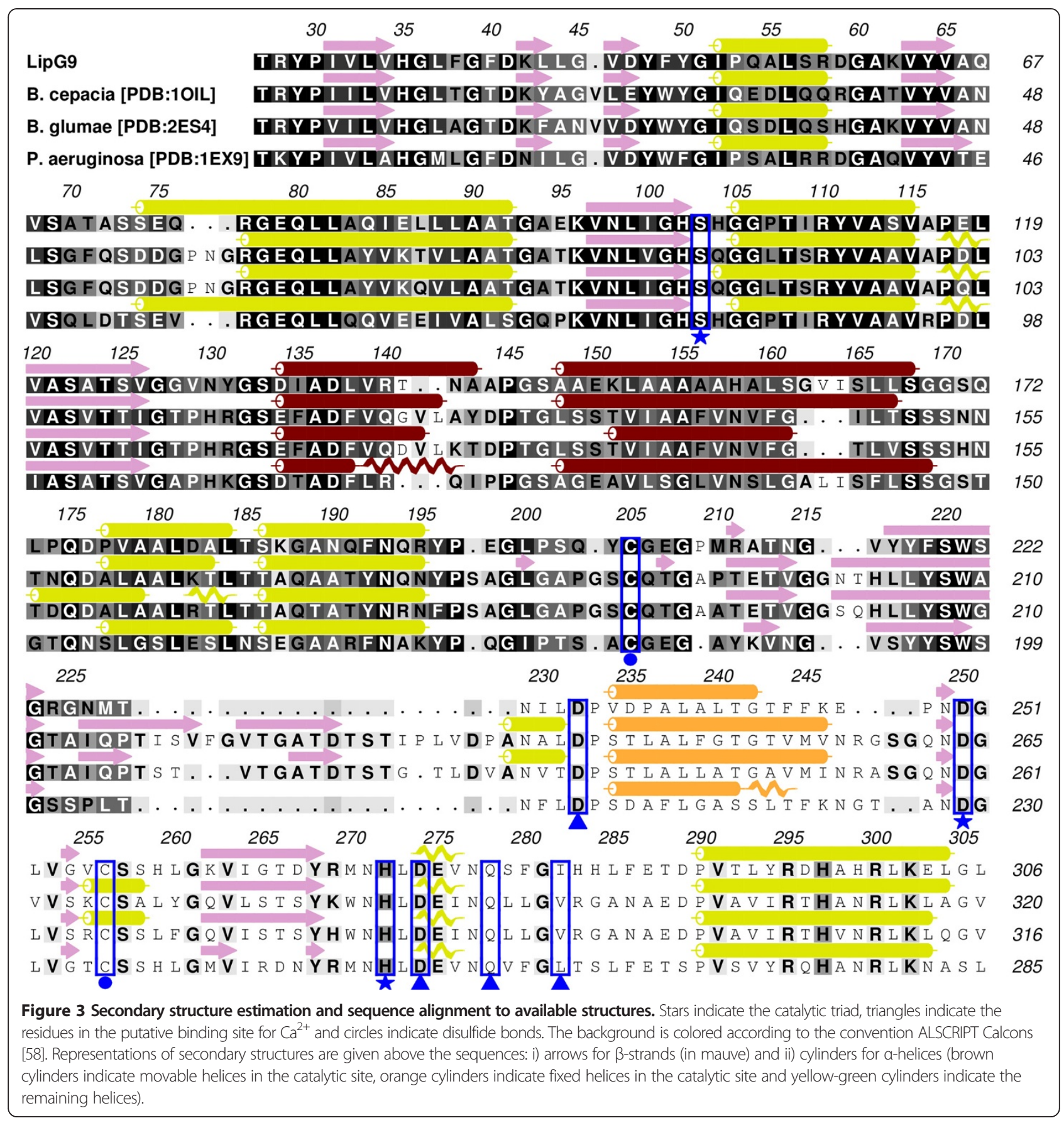

Pseudomonas sp. and $2800 \mathrm{U} \mathrm{mg}^{-1}$ for the lipase of $C$. viscosum.

The classification and structural characteristics of LipG9 The phylogenetic analysis classified LipG9 into the bacterial lipase subfamily I.1, which follows the Sec mechanism of secretion. This classification is confirmed by three features of LipG9. First, it has a calcium binding pocket that is absolutely conserved in lipases from subfamily I.1 [69]. Secondly, it has a disulfide bridge that is highly conserved in this subfamily. Thirdly, it requires a foldase, which is characteristic of lipases from subfamily I.1.

In LipG9-LifG9, the active construct contains the Histag on the $\mathrm{N}$-truncated terminal of the lipase. This His-tag is therefore far from the two residues of the catalytic triad that are located in the C-terminal region, $\mathrm{Asp}^{250}$ and $\mathrm{His}^{272}$ (Figures 3 and 4). In fact, the complete lack of activity of the co-expressions in which the His-tag was inserted at the C-terminal (Table 1) shows the importance of this region for LipG9 activity. This is not surprising, since this 

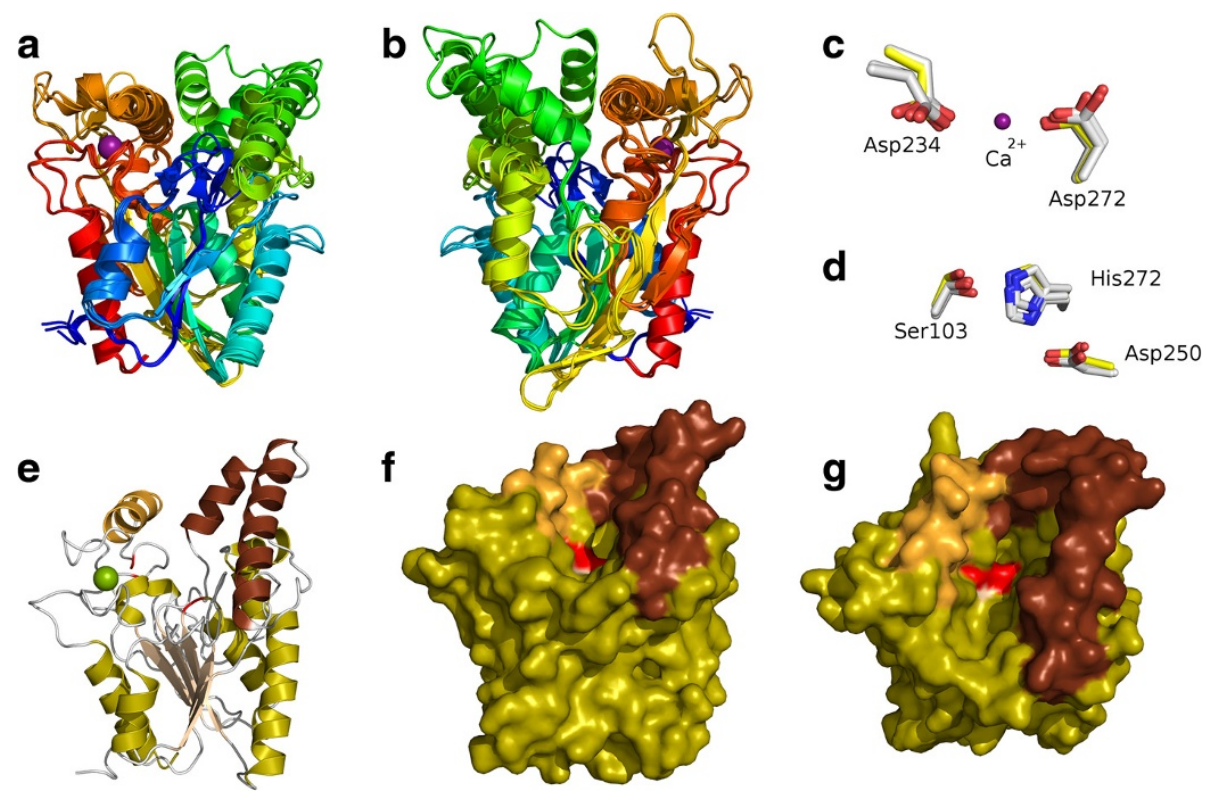

Figure 4 Homology model of LipG9. a) Homology-modeled LipG9 structure superimposed on the template structures. b) The same as Figure 4a, but rotated $180^{\circ}$. c) The calcium ion and its coordinating aspartate residues. d) The catalytic triad. e) The modeled structure, in the same orientation as in Figure $4 a$, but with its secondary structure highlighted according to Figure 3. f) A space filling model of Figure 4e. g) The same as Figure 4 , but rotated $45^{\circ}$.

region has been shown to be important for activity of many of the lipases that have been characterized to date [70,71].

\section{The kinetic characteristics of Lip-LifG9}

The high specific activity of Lip-LifG9 (i.e. a preparation containing both the lipase and the foldase) against olive oil, $1200 \mathrm{U} \mathrm{mg}^{-1}$, is comparable to values obtained with the most-used commercial lipases, for instance, those from Rhizopus oryzae, Rhizomucor miehei and Thermomyces lanuginosus (formerly Humicola lanuginosa), which have specific activities against olive oil of 1000, 3300 and $2900 \mathrm{U} \mathrm{mg}^{-1}$, respectively [72]. The fact that Lip-LifG9 has a high specific activity against this long chain substrate makes it a true metagenomic lipase [73,74]. Of the many hydrolytic enzymes isolated from metagenomics with claimed lipase activity $[14,27,29,31,64,75-78]$, only a few are active against long chain triacylglycerols $[19,24]$. Notably, Lip-LifG9 has a higher specific activity against triolein, another long chain triacylglycerol, than do some other true lipases obtained through metagenomics: Lip-LifG9 gave a specific activity of $817 \mathrm{U} \mathrm{mg}^{-1}$ with this substrate, while RlipE1 and RlipE2, isolated from a cow rumen metagenomic library [19], gave specific activities of 346 and $232 \mathrm{U} \mathrm{mg}^{-1}$, respectively.

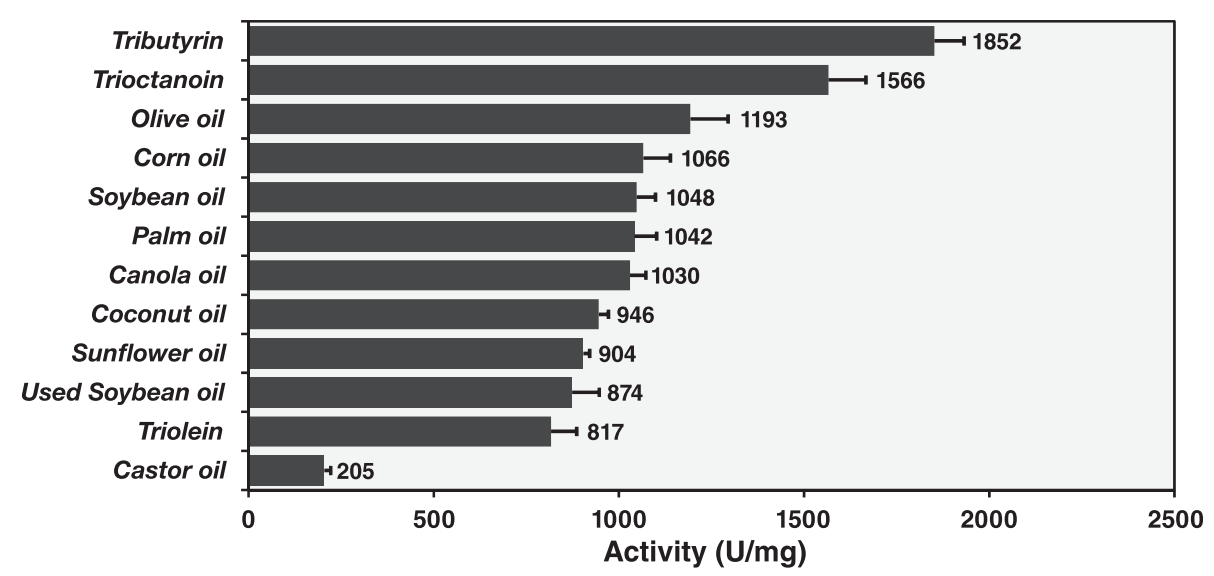

Figure 5 Enzymatic activity of Lip-LifG9 obtained using the titrimetric method with triacylglycerols. Assays were carried out using a pHStat, at $30^{\circ} \mathrm{C}$, with an emulsion containing $67 \mathrm{mmol} \mathrm{L} \mathrm{L}^{-1}$ of the substrates. The $\mathrm{pH}$ was maintained at 7.5. The assays were done in triplicate. The error bars represent the standard error of the mean. 


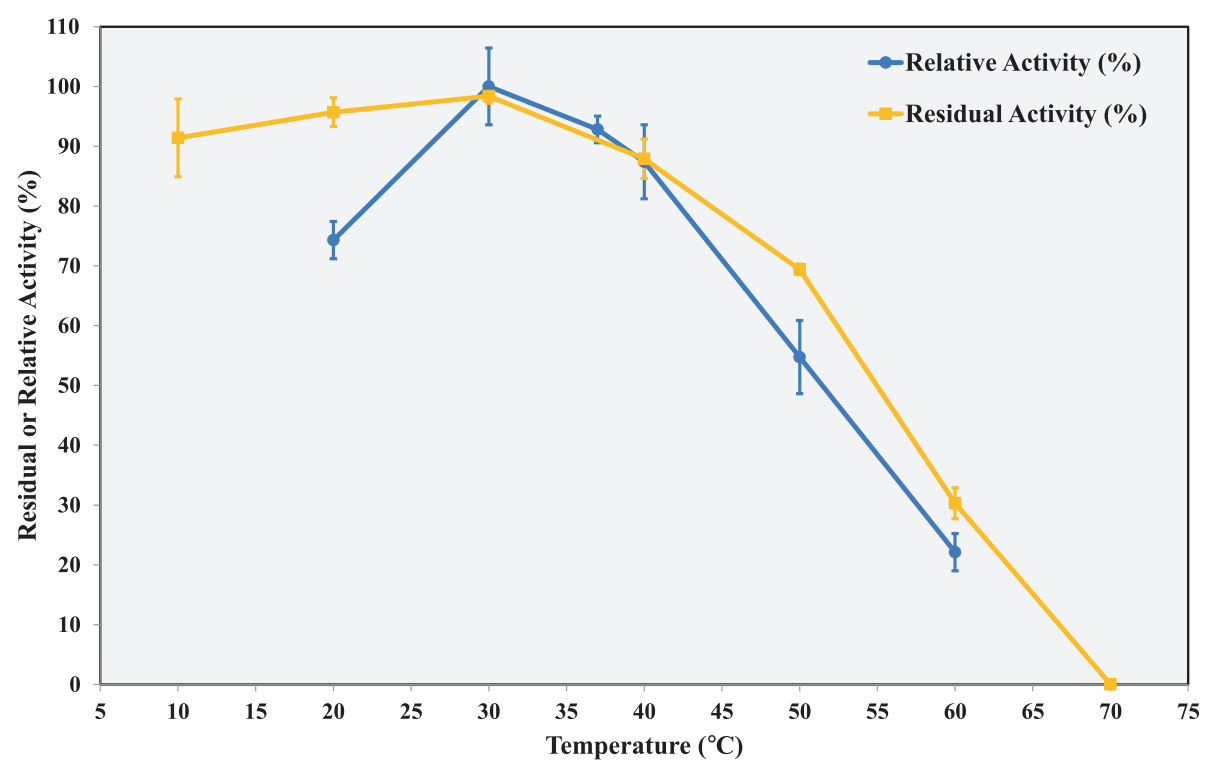

Figure 6 Effect of temperature on Lip-LifG9 activity and stability. In both studies, activity was determined by the titrimetric method with tricaprylin as the substrate, while in all incubations and assays the pH was 7.5. For the activity study, relative activities are plotted, with $100 \%$ corresponding to the activity at $30^{\circ} \mathrm{C}$. For the stability study, Lip-LifG9 was incubated for $1.5 \mathrm{~h}$ before determination of the residual activity and $100 \%$ corresponds to the activity after incubation at $30^{\circ} \mathrm{C}$. The assays were done in triplicate. The error bars represent the standard error of the mean.

Given the origin of the metagenomic library (i.e. fat-contaminated soil from the anaerobic lagoon of a wastewater treatment plant of a meat packing and dairy industry), it is not surprising that the lipase with which LipG9 showed the highest identity was from an Aeromonas species. In fact, our results for the activity and stability of LipG9 have similarities with those reported for several lipases from Aeromonas species. First, the temperature stability of Lip-LifG9 (Figure 6) is comparable to that of the lipases of A. caviae AU04 [79] and A. sobria LP004 [80], which kept $100 \%$ of their activities up to $40^{\circ} \mathrm{C}$ during $1.5 \mathrm{~h}$. Secondly, the wide range of $\mathrm{pH}$ for activity and stability (6.5 to 9.5) is also characteristic of lipases from Aeromonas species (A. hydrophila, A. caviae AU04) [79,81]. Thirdly, Lip-LifG9 had good stability in hydrophilic organic solvents such as DMSO, ethanol and

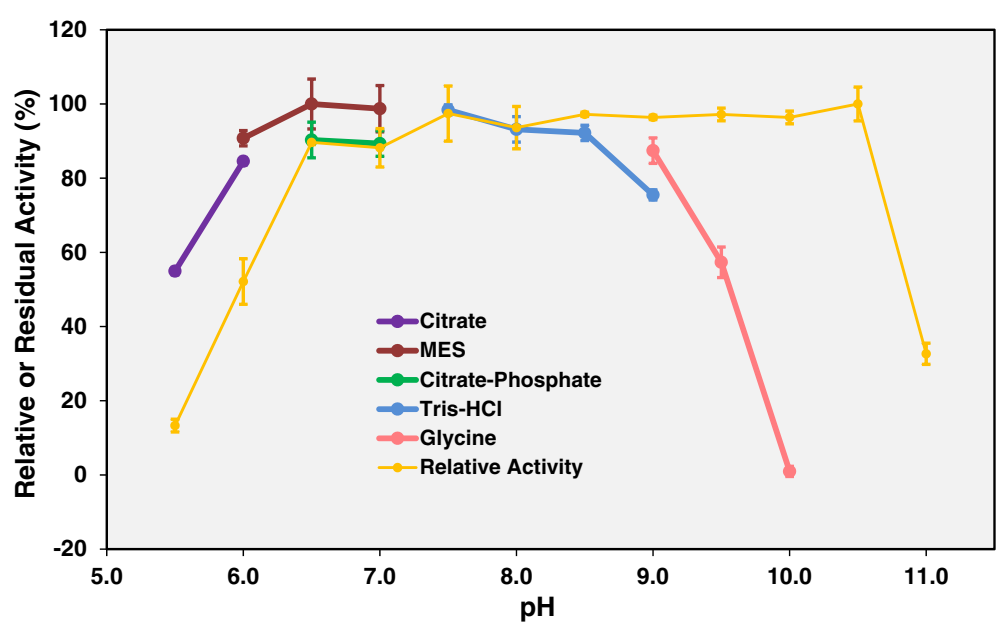

Figure 7 Effect of pH on Lip-LifG9 activity and stability. In both studies, activity was determined by the titrimetric method with tricaprylin as the substrate, while in all incubations and assays the temperature was $30^{\circ} \mathrm{C}$. For the activity study, relative activities are plotted (yellow line), with $100 \%$ corresponding to the activity at pH 7.5. For the stability study, Lip-LifG9 was incubated for $1.5 \mathrm{~h}$ in various buffers (all at $50 \mathrm{mmol}^{-1}$ ), as indicated by the other colored lines; residual activities were then determined at $\mathrm{pH} 7.5$, with $100 \%$ corresponding to the activity after $1.5 \mathrm{~h}$ incubation in Tris- $\mathrm{HCl}$ buffer at $\mathrm{pH}$ 7.5. The assays were done in triplicate. The error bars represent the standard error of the mean. 


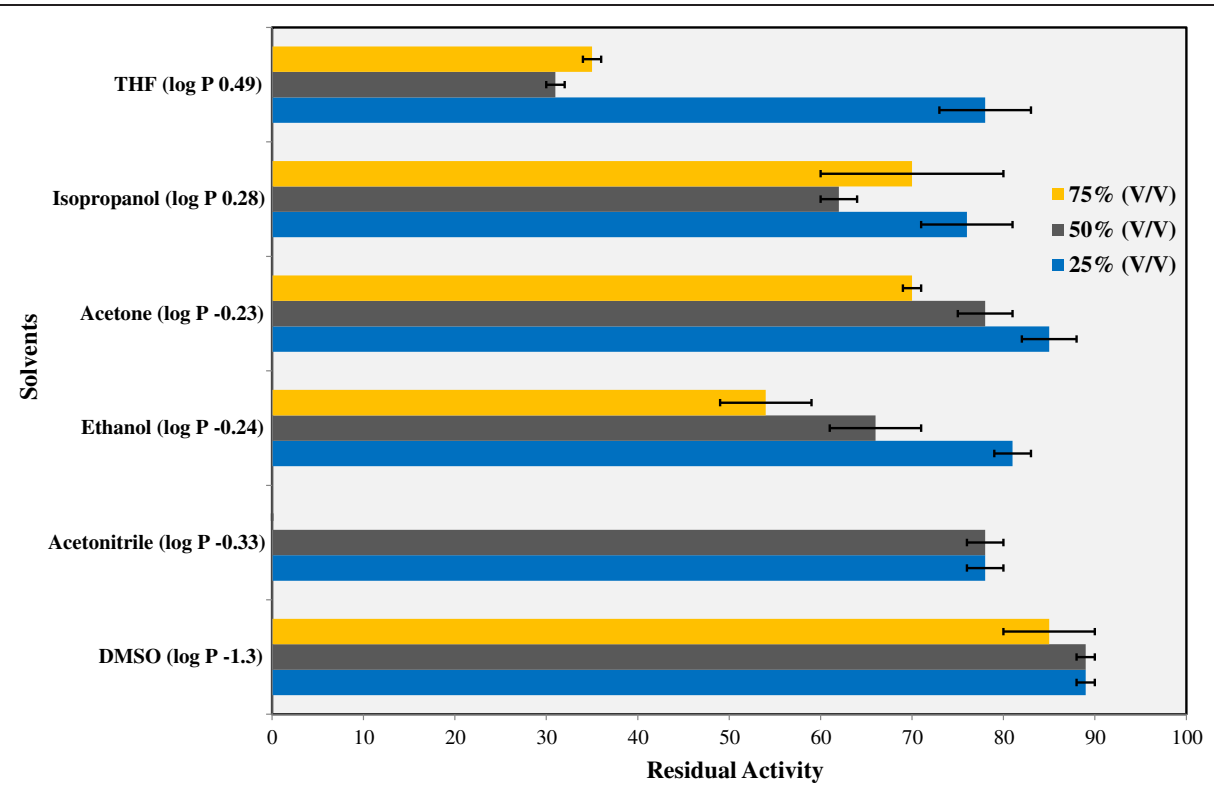

Figure 8 Stability of Lip-LifG9 in hydrophilic organic solvents. After incubation of Lip-LifG9 for $1.5 \mathrm{~h}$ in the solvents at 25, 50 and 75\% concentration, residual activities were determined by the titrimetric method with tricaprylin as the substrate, using a pHStat at pH 7.5 and $30^{\circ} \mathrm{C}$. In this case, $100 \%$ corresponds to the residual activity when Lip-LifG9 was incubated in 50 mmol L ${ }^{-1}$ Tris- $\mathrm{HCl}$ buffer, pH 7.5. The assays were done in triplicate. The error bars represent the standard error of the mean.

isopropanol, with the lipases of A. caviae AU04 [79] and Aeromonas sp. LPB 4 [82] showing comparable stabilities in isopropanol and ethanol. These characteristics suggest that it is worthwhile to undertake further studies to optimize the activity and stability of LipG9 and to investigate its potential for use in biocatalysis.

\section{Conclusions}

This paper is the first to report the successful coexpression of a lipase and its foldase from a metagenomic library. We used a simple and effective strategy, in which the genes of the lipase and of the foldase were cloned in different plasmids and inserted in a single heterologous host, E. coli BL21(DE3), enabling the purification of an active lipase-foldase complex. Phylogenetic analysis suggests that LipG9 belongs to the bacterial lipase subfamily I.1. The most similar sequences are those of the A. veronii lipase [GenBank:AEB48282], to which LipG9 has 96\% identity, and the $A$. veronii foldase [GenBank:AEB48281], to which LifG9 has $77 \%$ identity. The structural model of LipG9 presents both an overall folding and an active site structure that are quite similar to those of the homologue lipases used as templates. The LipG9 model also contains the calcium coordination site and the disulfide bridge that are highly conserved in subfamily I.1 lipases. The high activity of Lip-LifG9 towards various purified triglycerides and commercial oils, its broad range of $\mathrm{pH}$ stability and its stability in organic solvents suggest that it has a good potential for use in biocatalysis.

\section{Methods}

\section{Bacterial strains and plasmids}

Escherichia coli EPI300 ${ }^{\mathrm{mi}}$-T1R and pCC2FOS fosmid vector (CopyControl $^{\text {Ts }}$ Fosmid Library Production Kit, Epicentre Biotechnologies, Madison, USA) were used for constructing the metagenomic library [24]. EZ-Tn5 < KAN-2 > Insertion Kit (Epicentre) and DYEnamic ET Dye Terminator Kit (GE Life Sciences, Uppsala, Sweden) were used for sequencing. The NucleoSpin ${ }^{\circ}$ Extract II PCR purification kit was from Macherey-Nagel GmbH \& Co (Düren, Germany). The strains E. coli TOP10 (Invitrogen, Carlsbad, CA, USA) and BL21(DE3) (Novagen, Madison, MI, USA) and the vectors pET-28a(+), pET-29b(+) (also from Novagen) and pT7-7 (Addgene, Cambridge, MA, USA) were used as the recombinant protein expression system.

\section{Chemicals and enzymes}

Taq polymerase (MBI Fermentas, Baltimore, MD, USA) was used for DNA amplification. T4 DNA ligase, T4 DNA polymerase, Klenow fragment, T4 polynucleotide kinase, shrimp alkaline phosphatase (SAP), restriction enzymes and the protein molecular mass marker were purchased from Fermentas. The HiTrap Chelating HP column was purchased from GE Healthcare (Uppsala, Sweden). Triolein (65\%), tricaprylin (90\%) and tributyrin (99\%) were purchased from Sigma-Aldrich (St. Louis, MO, USA). The natural oils (olive, corn, canola, palm, sunflower, castor, coconut and soybean) for lipase analysis were commercial products purchased from a local supermarket. All other chemicals used for lipase analysis were of analytical grade. 


\section{Identification and sequencing of the lipase and foldase genes}

The clone with the genes lipg 9 and lifg9, for the lipase and foldase, respectively, was previously isolated from a metagenomic DNA library built from a fat-contaminated soil [24]. The plasmid DNA was isolated, by the alkaline lysis method [83], for template usage for PCR and for DNA sequencing. For the latter, a collection of derivative plasmids containing randomly inserted EZ-Tn $5<\mathrm{KAN}-2>$ was obtained by using an in vitro transposon insertion reaction with the EZTn5 < KAN-2 > Insertion Kit (Epicentre). These derivative plasmids were then used to generate new clones. Genes from 96 inactive clones were then sequenced with the $\mathrm{ABI}$ 377 (Genetic Analyzer, Applied Biosystems/HITACHI, Foster City, CA, USA) and MegaBACE 1000 (GE Healthcare, Uppsala, Sweden) sequencers, from both ends, using DYEnamic ET Dye Terminator Kit (GE Life Sciences). Sequence assembly and editing were performed with the CodonCode Aligner software (CodonCode Corporation, Centerville, MA, USA). The open reading frames (ORFs) were identified with the ORF Finder tool (NCBI) [84].

\section{Cloning of lipg9 and lifg9 genes}

Pairs of primers were designed for the lipase and the foldase, both entire and N-truncated, using the TMHMM v.2.0 [85], SignalP 3.0 [49] and ProtScale [48] servers, and obtained from Prodimol Biotechnologies (Belo Horizonte, MG, Brazil). Four lipase and two foldase constructs were prepared. They were first tested when expressed individually (Constructs \# 1 to \# 6 in Table 1). They were then combined for eight different co-expression experiments (Constructs \# 1-5 to \# 4-6 in Table 1).

Expression assays were carried out for the individual and associated proteins (i.e. co-expressed in E. coli). As shown in Table 1, the His-tag was always on the N-truncated end of active LipG9. The entire and the N-truncated fragments of lipg9, with 918 and 843 bp, respectively, and of lifg9, with 720 and 621 bp, respectively, were amplified separately by the polymerase chain reaction (PCR), using the fosmidial pCC2FOS-lip-lifg9 DNA. PCR was performed with Taq polymerase. The resultant PCR product and the expression vectors pT7-7 and pET29b(+) or pET28a(+) were then digested with NdeI and HindIII. The digested PCR product was purified using the NucleoSpin Extract II PCR purification kit, according to the manufacturer's instructions. Digested plasmids were purified by phenol chloroform extraction followed by ethanol precipitation [83]. The inserts for entire and N-truncated lipg 9 and lifg 9 were ligated into the vectors. Plasmids were sequenced and then introduced through thermal shock into competent E. coli BL21(DE3) cells to express the recombinant LipG9 active lipase.

The E. coli TOP10 and BL21(DE3) cells with the genes lipg9 or lifg 9 were stored at $-80^{\circ} \mathrm{C}$. Tests for expression of the constructs in E. coli BL21(DE3) cells were carried out
(Table 1). The cells were collected and then transferred to $75 \mathrm{~mL}$ of Luria Bertani (LB) medium, with either $100 \mathrm{mg} \mathrm{mL}^{-1}$ kanamycin (lipg9) or $50 \mathrm{mg} \mathrm{mL}^{-1}$ ampicillin (lifg9). After the culture reached an $\mathrm{OD}_{600}$ of 0.5 , IPTG was added to give a concentration of $0.2 \mathrm{mmol} \mathrm{L}^{-1}$ and the culture was continued for another $16 \mathrm{~h}$ at $20^{\circ} \mathrm{C}$. The supernatant was discarded and the cell pellet was resuspended in $7 \mathrm{~mL}$ of a buffer containing $2.5 \mathrm{mmol} \mathrm{L}^{-1}$ Tris- $\mathrm{HCl}, 4 \mathrm{mmol} \mathrm{L}^{-1} \mathrm{CaCl}_{2}, 1 \%(\mathrm{~V} / \mathrm{V})$ Triton $\mathrm{X}-100$ and $150 \mathrm{mmol} \mathrm{L}^{-1} \mathrm{NaCl}$. The cells were sonicated in an ice bath ten times for $30 \mathrm{~s}$ with an interval of $30 \mathrm{~s}$. The expression of the enzyme was confirmed both by $12 \%$ (w/V) SDS-PAGE [86] and by activity assays, done using the titrimetric method with tricaprylin as substrate $(90 \%)$ in a $\mathrm{pH}-$ Stat [87].

\section{Co-expression and purification of complexed LipG9-LifG9}

The lipase and foldase were co-expressed in different combinations (Table 1) within competent E. coli BL21 (DE3) cells, in which the lipase plasmid was introduced before the foldase plasmid. The assays for activity determination of the co-expression combinations were performed by the titrimetric method with tricaprylin as the substrate, as described below. The best combination was determined as \# 4-6 (Table 1) and this combination was further purified.

After sonication, the cell lysate obtained from $2 \mathrm{~L}$ of culture medium with the strain E. coli BL21(DE3) transformed with combination \# 4-6 (Table 1) was loaded onto a HiTrap column equilibrated with $50 \mathrm{mmol} \mathrm{\textrm {L } ^ { - 1 }}$ Tris- $\mathrm{HCl}$ buffer (pH 7.5), containing $5 \mathrm{mmol} \mathrm{L}^{-1} \mathrm{CaCl}_{2}, 500 \mathrm{mmol} \mathrm{L} \mathrm{L}^{-1}$ $\mathrm{NaCl}, 10 \mathrm{mmol} \mathrm{L}^{-1} \beta$-mercaptoethanol, $10 \%$ (V/V) glycerol, $1 \%(\mathrm{~V} / \mathrm{V})$ Triton $\mathrm{X}-100$ and $10 \mathrm{mmol} \mathrm{L}^{-1}$ imidazole. The column was then washed extensively with the same solution. A linear gradient $\left(10-1000 \mathrm{mmol} \mathrm{L}^{-1}\right)$ of imidazole in $50 \mathrm{mmol} \mathrm{L}{ }^{-1}$ Tris- $\mathrm{HCl}$ buffer ( $\mathrm{pH} \mathrm{7.5)} \mathrm{containing} 10 \%$ $(\mathrm{V} / \mathrm{V})$ glycerol at a flow rate of $0.2 \mathrm{~mL} \mathrm{~min}^{-1}$ was then applied and fractions of $1.5 \mathrm{~mL}$ were collected. The fractions identified as containing proteins of the expected molecular masses (through SDS-PAGE) were pooled and dialyzed against a buffer consisting of $50 \mathrm{mmol} \mathrm{L}^{-1}$ Tris- $\mathrm{HCl}$ (pH 7.5), $150 \mathrm{mmol} \mathrm{L}^{-1} \mathrm{NaCl}$ and glycerol 20\% (V/V) for $12 \mathrm{~h}$, with two buffer exchanges.

\section{Electrophoresis and determination of protein content}

Electrophoresis of protein samples was done with $12 \%$ (w/V) SDS-PAGE [86]. The gel was stained with Coomassie Brilliant Blue R-250 and destained with methanol/aceticacid/water $(5 / 1 / 4, \mathrm{~V} / \mathrm{V} / \mathrm{V})$. Densitometric analysis of the SDS-PAGE gel was done using the LabWorks Image Acquisition and Analysis software 4.0 (UVP BioImaging Systems, Upland, CA, USA). The protein concentration was determined by the Bradford method [88] using bovine serum 
albumin (Sigma Chemical Co., St. Louis, MO, USA) as the standard.

\section{MALDI-TOF/MS analysis}

Spots corresponding to the N-truncated lipase and the Ntruncated foldase were excised manually from an SDSPAGE gel for analysis by matrix-assisted laser desorption/ ionization (MALDI) time-of-flight (TOF) mass spectrometry (MS). Excised spots were in-gel digested with sequencing grade modified trypsin (Promega, Madison, WI, USA) as described elsewhere [89]. The sample was desalted using a ZipTipC $_{18}$ pipette tip (Millipore Corporation, Billerica, MA, USA) and eluted directly onto the MALDI target plate coated with MALDI matrix (saturated solution of $\alpha$-cyano4-hydroxycinnamic acid in 50\% (V/V) acetonitrile and 0.1\% trifluoroacetic acid). MALDI-TOF data were acquired with an Autoflex II spectrometer (Bruker Daltonics, Bremen, HB, Germany) in the reflector positive ion mode with an acceleration voltage of $20 \mathrm{kV}$, delay time of $150 \mathrm{~ns}$ and acquisition mass range of 800-3200 $\mathrm{Da}$. The mass profiles obtained were compared with the peptide masses predicted by in silico digestion of the His-tagged protein sequence using the PeptideCutter and MS-Digest tools [48].

\section{Lipase sequence analysis and phylogenetic tree construction}

To determine the lipase family, the LipG9 sequence was analyzed against the 25 lipase sequences that Arpingy and Jaeger [43] classified into lipase subfamilies I.1 and I.2 This lipase classification scheme is based on conserved sequence motifs and biological properties. Eight other sequences that had a high identity to LipG9, as determined by a BLAST (NCBI) [90], were also aligned. The ProtParam tool was used to calculate the theoretical parameters of the protein [48] and multiple sequence alignment was performed with the ClustalW algorithm [91]. Phylogenetic analysis was carried out with the neighbor-joining method using the MEGA software (version 6). Bootstrapping (10000 replicates) was used to estimate the confidence levels of the phylogenetic reconstructions [56].

A BLAST (NCBI) alignment of the lipase sequence against the PDB [57] identified the sequences with the greatest similarity. The programs DSSP [92], Jpred3 [93] and Aline [94] were used to estimate and to show the predicted secondary structure.

\section{Structural homology modeling}

Homology modeling was carried out using MODELLER software [95]. Suitable experimental structural homologues to use as templates were chosen using the MHOLline algorithm [96] and acquired from the PDB [57]. The templates were superimposed with the
Multiprot program [97] and then used to perform sequence alignments with the program T-Coffee [98]. Five hundred models that included the calcium ion were generated and further optimized by means of the variable target function method (VTFM), available within MODELLER. The quality of the models was assessed by the programs PROCHECK [99], WHATCHECK [100] and MODELLER with the embedded normalized DOPE [101] and GA3415 scores [102].

\section{Titrimetric determinations of lipase activity using triacylglycerols}

During the purification procedure described above, LipG9 and LifG9 were co-eluted from the affinity column. This preparation, denominated Lip-LifG9, was used in the investigations of lipase activity.

The substrate emulsions consisted of $67 \mathrm{mmol} \mathrm{L}^{-1}$ triacylglycerol, $3 \%(\mathrm{w} / \mathrm{V})$ gum arabic, $2 \mathrm{mmol} \mathrm{L}^{-1} \mathrm{CaCl}_{2}$, $2.5 \mathrm{mmol} \mathrm{L}^{-1}$ Tris- $\mathrm{HCl}$ and $150 \mathrm{mmol} \mathrm{L}^{-1} \mathrm{NaCl}$, dispersed in distilled water [87] and emulsified with a handheld mixer (400 watts, Royal Philips Electronics, Amsterdam, NH, Netherlands) at high speed, initially for $10 \mathrm{~min}$ and then for an additional 2 min immediately before use. The free fatty acids released during the reaction were titrated automatically to $\mathrm{pH} 7.5$ in a Metrohm 718 STAT Titrino potentiometric titrator (Metrohm, Herisau, AR, Switzerland) with $0.05 \mathrm{~mol} \mathrm{~L}^{-1} \mathrm{NaOH}$, for $5 \mathrm{~min}$. The reactions were carried out in a glass vessel at $30^{\circ} \mathrm{C}$ (unless otherwise stated) with $20 \mathrm{~mL}$ of substrate emulsion and $200 \mu \mathrm{L}$ of solution buffer $\left(2.5 \mathrm{mmol} \mathrm{L}^{-1}\right.$ Tris- $\mathrm{HCl} \mathrm{pH} 7.5,2 \mathrm{mmol} \mathrm{L} \mathrm{L}^{-1} \mathrm{CaCl}_{2}$ ) containing $0.025 \mathrm{mg}$ of purified Lip-LifG9. All measurements were performed in triplicate and results are expressed as the average of these triplicate measurements \pm the standard error of the mean. One unit (U) of lipase activity was defined as the release of $1 \mu \mathrm{mol}$ of fatty acid per minute. The effects of $\mathrm{pH}$ (5.0 to 11.0 , at $30^{\circ} \mathrm{C}$ ) and temperature (20 to $60^{\circ} \mathrm{C}$, at $\mathrm{pH} 7.5$ ) on the activity of Lip-LifG9 were determined using tricaprylin as the substrate. The substrate emulsion and reaction conditions were the same as described above, except that the titration point was set at the stated value. Corrections were made for the partial dissociation of octanoic acid, assuming a $\mathrm{pK}_{\mathrm{a}}$ of 4.89 .

The activity of Lip-LifG9 was also determined against several triacylglycerols (triolein, tricaprylin and tributyrin and commercial oils from olive, corn, canola, palm, sunflower, castor, coconut and soybean). The emulsions were prepared with the corresponding triacylglycerols and oils, with the reactor maintained at $\mathrm{pH} 7.5$ and $30^{\circ} \mathrm{C}$.

The temperature stability of Lip-LifG9 was investigated by determining the residual activity, measured at $30^{\circ} \mathrm{C}$ and $\mathrm{pH} 7.5$, after $1.5 \mathrm{~h}$ incubation at values from 0 to $80^{\circ} \mathrm{C}$. To determine the $\mathrm{pH}$ stability, Lip-LifG9 was incubated for 
$1.5 \mathrm{~h}$ at $30^{\circ} \mathrm{C}$ in the buffers citrate (pH 5.5 and 6.0), MES (pH 5.5 to 7.0), citrate-phosphate ( $\mathrm{pH} 6.5$ and 7.0), Tris$\mathrm{HCl}$ (pH 7.5 to 9.0) and glycine- $\mathrm{NaOH}$ (pH 9.0 to 10.0), at $50 \mathrm{mmol} \mathrm{L}^{-1}$ concentration, with the residual activity determined at $\mathrm{pH} 7.5$ and $30^{\circ} \mathrm{C}$. Tricaprylin was used as the substrate in both residual activity determinations.

The stability in hydrophilic organic solvents was determined by incubating Lip-LifG9 for $1.5 \mathrm{~h}$ at $30^{\circ} \mathrm{C}$ in aqueous solutions containing the solvents dimethylsulfoxide (DMSO, $\log \mathrm{P}-1.3)$, acetonitrile ( $\log \mathrm{P}-0.33$ ), ethanol ( $\log \mathrm{P}-0.24)$, acetone $(\log \mathrm{P}-0.23)$, isopropanol $(\log$ P 0.28$)$ and tetrahydrofuran (THF, $\log$ P 0.49$)$ at the concentrations of 25,50 and $75 \%(\mathrm{~V} / \mathrm{V})$. A solution of Lip-LifG9 $(10 \mu \mathrm{L})$ containing $0.025 \mathrm{mg}$ of protein was added to $2 \mathrm{~mL}$ of solvent solution. After the incubation, $40 \mu \mathrm{L}$ of the medium was taken and added directly to the reaction vessel of the $\mathrm{pH}$-Stat, where the residual activities against tricaprylin were determined at $\mathrm{pH} 7.5$ and $30^{\circ} \mathrm{C} .100 \%$ activity was taken as that obtained after incubation in an aqueous buffer $\left(50 \mathrm{mmol} \mathrm{L}^{-1}\right.$ Tris$\mathrm{HCl}, \mathrm{pH}$ 7.5) solution for $1.5 \mathrm{~h}$.

\section{Nucleotide sequence accession number}

The lipG9 and lifG9 nucleotide sequences reported here are available in the GenBank database under the accession numbers [GenBank:KM023399] and [GenBank: KM023400], respectively.

\section{Competing interests}

The authors declare that they have no competing interests.

\section{Authors' contributions \\ NK, FOP and EMS conceived, supervised and coordinated this study. VPM carried out the sequencing and cloning steps, protein purification and enzyme analyses. AG participated in the experimental design. MM-S contributed to cloning steps. II and VPM built, validated and performed structural analyses of the homology model. VPM, NK, Jl and DAM contributed to the analysis and interpretation of data and to the writing of the manuscript. EMS, MM-S, JI and AG critically revised the manuscript. All authors read and approved the final manuscript.}

\section{Acknowledgements}

This work was supported by INCT-FBN/CNPq/MCT, CAPES, Institutos do Milênio/ CNPq/MCT and PRONEX/Fundação Araucária. We thank the Brazilian National Council for Scientific and Technological Development (CNPq) and the Coordination for the Development of Higher Education Personnel (CAPES) for research scholarships. We thank Roseli Prado, Julieta Pie, Marilza Doroti Lamour and Valter A. de Baura for technical support.

\footnotetext{
Author details

1Departamento de Química, Universidade Federal do Paraná, Cx. P. 19081 Centro Politécnico, Curitiba 81531-980, Paraná, Brazil. '2Instituto Federal do Paraná - Campus Irati, Rua Pedro Koppe, 100, Irati 84500-000Paraná, Brazil. ${ }^{3}$ Departamento de Bioquímica e Biologia Molecular, Universidade Federal do Paraná, Cx. P. 19046, Centro Politécnico, Curitiba 81531-980Paraná, Brazil. ${ }^{4}$ Agência Tecpar de Inovação, Instituto de Tecnologia do Paraná - Tecpar, Curitiba 81350-010Paraná, Brazil. ${ }^{5}$ Departamento de Química, Universidade Estadual de Ponta Grossa, Av. Carlos Cavalcanti, 4748, Ponta Grossa 84070-900Paraná, Brazil.
}

Received: 6 October 2014 Accepted: 20 November 2014

Published online: 16 December 2014

\section{References}

1. Haki G: Developments in industrially important thermostable enzymes: a review. Bioresour Technol 2003, 89:17-34.

2. Hasan F, Shah AA, Hameed A: Industrial applications of microbial lipases. Enzyme Microb Technol 2006, 39:235-251.

3. Kumar S, Kikon K, Upadhyay A, Kanwar SS, Gupta R: Production, purification, and characterization of lipase from thermophilic and alkaliphilic Bacillus coagulans BTS-3. Protein Expr Purif 2005, 41:38-44.

4. Fernandes MLM, Krieger N, Baron AM, Zamora PP, Ramos LP, Mitchell DA: Hydrolysis and synthesis reactions catalysed by Thermomyces lanuginosa lipase in the AOT/lsooctane reversed micellar system. J Mol Catal B Enzym 2004, 30:43-49.

5. Abbas H, Comeau L: Aroma synthesis by immobilized lipase from Mucor sp. Enzyme Microb Technol 2003, 32:589-595.

6. Baron AM, Zago EC, Mitchell DA, Krieger N: SPIL: Simultaneous production and immobilization of lipase from Burkholderia cepacia LTEB11. Biocatal Biotransformation 2011, 29:19-24.

7. Salum TFC, Villeneuve P, Barea B, Yamamoto Cl, Côcco LC, Mitchell DA, Krieger N: Synthesis of biodiesel in column fixed-bed bioreactor using the fermented solid produced by Burkholderia cepacia LTEB11. Process Biochem 2010, 45:1348-1354.

8. Salum TFC, Baron AM, Zago E, Turra V, Baratti J, Mitchell DA, Krieger N: An efficient system for catalyzing ester synthesis using a lipase from a newly isolated Burkholderia cepacia strain. Biocatal Biotransformation 2008, 26:197-203.

9. Fernandes MLM, Saad EB, Meira JA, Ramos LP, Mitchell DA, Krieger N: Esterification and transesterification reactions catalysed by addition of fermented solids to organic reaction media. J Mol Catal B Enzym 2007, 44:8-13.

10. Soliman NA, Knoll M, Abdel-Fattah YR, Schmid RD, Lange S: Molecular cloning and characterization of thermostable esterase and lipase from Geobacillus thermoleovorans YN isolated from desert soil in Egypt. Process Biochem 2007, 42:1090-1100.

11. Salis A, Pinna M, Monduzzi M, Solinas V: Biodiesel production from triolein and short chain alcohols through biocatalysis. J Biotechnol 2005, 119:291-299.

12. Baron AM, Sarquis MIM, Baigori M, Mitchell DA, Krieger N: A comparative study of the synthesis of $n$-butyl-oleate using a crude lipolytic extract of Penicillum coryophilum in water-restricted environments. J Mol Catal B Enzym 2005, 34:25-32.

13. Rasera K, Osório NM, Mitchell DA, Krieger N, Ferreira-Dias S: Interesterification of fat blends using a fermented solid with lipolytic activity. J Mol Catal B Enzym 2012, 76:75-81.

14. Elend C, Schmeisser C, Leggewie C, Babiak P, Carballeira JD, Steele HL, Reymond $J$, Jaeger KE, Streit WR: Isolation and biochemical characterization of two novel metagenome-derived esterases. Appl Environ Microbiol 2006, 72:3637-3645.

15. Bevilaqua JV, Pinto JC, Lima LM, Barreiro EJ, Alves TLM, Freire DMG: Enzymatic hydrolysis by immobilized lipase applied to a new prototype anti-asthma drug. Biochem Eng J 2004, 21:103-110.

16. Lozano P: Synthesis of glycidyl esters catalyzed by lipases in ionic liquids and supercritical carbon dioxide. J Mol Catal A Chem 2004 214:113-119.

17. Otten LG, Hollmann F, Arends IW: Enzyme engineering for enantioselectivity: from trial-and-error to rational design? Trends Biotechnol 2010, 28:46-54.

18. Böttcher D, Bornscheuer UT: Protein engineering of microbial enzymes. Curr Opin Microbiol 2010, 13:274-282.

19. Liu K, Wang J, Bu D, Zhao S, McSweeney C, Yu P, Li D: Isolation and biochemical characterization of two lipases from a metagenomic library of China Holstein cow rumen. Biochem Biophys Res Commun 2009, 385:605-611.

20. Sharma PK, Singh K, Singh R, Capalash N, Ali A, Mohammad O, Kaur J: Characterization of a thermostable lipase showing loss of secondary structure at ambient temperature. Mol Biol Rep 2012, 39:2795-2804.

21. Rhee JK, Ahn DG, Kim YG, Oh JW: New thermophilic and thermostable esterase with sequence similarity to the hormone-sensitive lipase family, cloned from a metagenomic library. Appl Environ Microbiol 2005, 71:817-825.

22. Zheng J, Liu C, Liu L, Jin Q: Characterisation of a thermo-alkali-stable lipase from oil-contaminated soil using a metagenomic approach. Syst Appl Microbiol 2013, 36:197-204. 
23. Fan X, Liu X, Wang K, Wang S, Huang R, Liu Y: Highly soluble expression and molecular characterization of an organic solvent-stable and thermotolerant lipase originating from the metagenome. J Mol Catal B Enzym 2011, 72:319-326.

24. Glogauer A, Martini VP, Faoro H, Couto GH, Muller-Santos M, Monteiro RA, Mitchell DA, de Souza EM, Pedrosa FO, Krieger N: Identification and characterization of a new true lipase isolated through metagenomic approach. Microb Cell Fact 2011, 10:54.

25. Elend C, Schmeisser C, Hoebenreich H, Steele HL, Streit WR: Isolation and characterization of a metagenome-derived and cold-active lipase with high stereospecificity for (R)-ibuprofen esters. J Biotechnol 2007, 130:370-377.

26. Khan $M$, Jithesh $K$ : Expression and purification of organic solvent stable lipase from soil metagenomic library. World J Microbiol Biotechnol 2012, 28:2417-2424

27. Lammle K, Zipper H, Breuer M, Hauer B, Buta C, Brunner H, Rupp S: Identification of novel enzymes with different hydrolytic activities by metagenome expression cloning. J Biotechnol 2007, 127:575-592.

28. Peng Q, Wang X, Shang M, Huang J, Guan G, Li Y, Shi B: Isolation of a novel alkaline-stable lipase from a metagenomic library and its specific application for milkfat flavor production. Microb Cell Fact 2014, 13:1.

29. Jeon JH, Kim JT, Kim YJ, Kim HK, Lee HS, Kang SG, Kim SJ, Lee JH: Cloning and characterization of a new cold-active lipase from a deep-sea sediment metagenome. App/ Microbiol Biotechnol 2009, 81:865-874.

30. Kennedy J, Marchesi JR, Dobson AD: Marine metagenomics: strategies for the discovery of novel enzymes with biotechnological applications from marine environments. Microb Cell Fact 2008, 7:27.

31. Hardeman F, Sjoling S: Metagenomic approach for the isolation of a novel low-temperature-active lipase from uncultured bacteria of marine sediment. FEMS Microbiol Ecol 2007, 59:524-534.

32. Fu J, Leiros HK, de Pascale D, Johnson KA, Blencke HM, Landfald B: Functional and structural studies of a novel cold-adapted esterase from an Arctic intertidal metagenomic library. Appl Microbiol Biotechnol 2013, 97:3965-3978.

33. Jeon JH, Kim JT, Kang SG, Lee JH, Kim SJ: Characterization and its potential application of two esterases derived from the arctic sediment metagenome. Mar Biotechnol (NY) 2009, 11:307-316.

34. Rashamuse K, Magomani V, Ronneburg T, Brady D: A novel family VIII carboxylesterase derived from a leachate metagenome library exhibits promiscuous beta-lactamase activity on nitrocefin. Appl Microbiol Biotechnol 2009, 83:491-500.

35. Wang S, Wang K, Li L, Liu Y: Isolation and characterization of a novel organic solvent-tolerant and halotolerant esterase from a soil metagenomic library. J Mol Catal B Enzym 2013, 95:1-8.

36. Selvin J, Kennedy J, Lejon DP, Kiran GS, Dobson AD: Isolation identification and biochemical characterization of a novel halo-tolerant lipase from the metagenome of the marine sponge Haliclona simulans. Microb Cell Fact 2012, 11:72

37. Morohoshi T, Oikawa M, Sato S, Kikuchi N, Kato N, Ikeda T: Isolation and characterization of novel lipases from a metagenomic library of the microbial community in the pitcher fluid of the carnivorous plant Nepenthes hybrida. J Biosci Bioeng 2011, 112:315-320.

38. Faoro H, Glogauer A, Souza EM, Rigo LU, Cruz LM, Monteiro RA, Pedrosa FO: Identification of a new lipase family in the Brazilian Atlantic Forest soil metagenome. Environ Microbiol Rep 2011, 3:750-755.

39. Couto GH, Glogauer A, Faoro H, Chubatsu LS, Souza EM, Pedrosa FO: Isolation of a novel lipase from a metagenomic library derived from mangrove sediment from the south Brazilian coast. Genet Mol Res 2010, 9:514-523.

40. Kim YH, Kwon EJ, Kim SK, Jeong YS, Kim J, Yun HD, Kim H: Molecular cloning and characterization of a novel family VIII alkaline esterase from a compost metagenomic library. Biochem Biophys Res Commun 2010, 393:45-49.

41. Wei P, Bai L, Song W, Hao G: Characterization of two soil metagenome-derived lipases with high specificity for p-nitrophenyl palmitate. Arch Microbiol 2009, 191:233-240

42. Rosenau F, Tommassen J, Jaeger KE: Lipase-specific foldases. Chembiochem 2004, 5:152-161.

43. Arpigny $\mathrm{J}$, Jaeger KE: Bacterial lipolytic enzymes: classification and properties. Biochem J 1999, 343(Pt 1):177-183.

44. Quyen DT, Schmidt-Dannert C, Schmid RD: High-level formation of active Pseudomonas cepacia lipase after heterologous expression of the encoding gene and its modified chaperone in Escherichia coli and rapid in vitro refolding. Appl Environ Microbiol 1999, 65:787-794.
45. Traub PC, Schmidt-Dannert C, Schmitt J, Schmid RD: Gene synthesis, expression in E. coli, and in vitro refolding of Pseudomonas sp. KWI 56 and Chromobacterium viscosum lipases and their chaperones. Appl Microbiol Biotechnol 2001, 55:198-204.

46. Quyen TD, Vu CH, Le GT: Enhancing functional production of a chaperone-dependent lipase in Escherichia coli using the dual expression cassette plasmid. Microb Cell Fact 2012, 11:29.

47. Hobson AH, Buckley CM, Aamand JL, Jorgensen ST, Diderichsen B McConnell DJ: Activation of a bacterial lipase by its chaperone. Proc Natl Acad Sci U S A 1993, 90:5682-5686.

48. Wilkins MR, Gasteiger E, Bairoch A, Sanchez JC, Williams KL, Appel RD, Hochstrasser DF: Protein identification and analysis tools in the ExPASy server. Methods Mol Biol 1999, 112:531-552.

49. Bendtsen JD, Nielsen H, von Heijne G, Brunak S: Improved prediction of signal peptides: SignalP 3.0. J Mol Biol 2004, 340:783-795.

50. Wilhelm S, Rosenau F, Becker S, Buest S, Hausmann S, Kolmar H, Jaeger KE: Functional cell-surface display of a lipase-specific chaperone. Chembiochem 2007, 8:55-60.

51. Rosenau F, Jaeger K: Bacterial lipases from Pseudomonas: regulation of gene expression and mechanisms of secretion. Biochimie 2000, 82:1023-1032.

52. Pauwels K, Lustig A, Wyns L, Tommassen J, Savvides SN, Van Gelder P: Structure of a membrane-based steric chaperone in complex with its lipase substrate. Nat Struct Mol Biol 2006, 13:374-375.

53. El Khattabi M, Van Gelder P, Bitter W, Tommassen J: Role of the lipasespecific foldase of Burkholderia glumae as a steric chaperone. J Biol Chem 2000, 275:26885-26891.

54. Pemberton JM, Kidd SP, Schmidt R: Secreted enzymes of Aeromonas. FEMS Microbiol Lett 1997, 152:1-10.

55. Huang L, Hansen KC, Allen NP, Chalkley RJ, Burlingame AL, Rexach M, Baker PR: Comprehensive analysis of a multidimensional liquid chromatography mass spectrometry dataset acquired on a quadrupole selecting, quadrupole collision cell, time-of-flight mass spectrometer: II. New developments in Protein Prospector allow for reliable and comprehensive automatic analysis of large datasets. Mol Cell Proteomics 2005, 4:1194-1204.

56. Tamura K, Stecher G, Peterson D, Filipski A, Kumar S: MEGA6: Molecular Evolutionary Genetics Analysis version 6.0. Mol Biol Evol 2013, 30:2725-2729.

57. Berman HM, Westbrook J, Feng Z, Gilliland G, Bhat TN, Weissig H, Shindyalov IN, Bourne PE: The protein data bank. Nucleic Acids Res 2000 28:235-242

58. Barton GJ: ALSCRIPT: a tool to format multiple sequence alignments. Protein Eng 1993, 6:37-40.

59. Sharma R, Soni SK, Vohra RM, Gupta LK, Gupta JK: Purification and characterisation of a thermostable alkaline lipase from a new thermophilic Bacillus sp. RSJ-1. Process Biochem 2002, 37:1075-1084.

60. Brumlik MJ, van der Goot FG, Wong KR, Buckley J: The disulfide bond in the Aeromonas hydrophila lipase/acyltransferase stabilizes the structure but is not required for secretion or activity. J Bacterio/ 1997, 179:3116-3121.

61. Kranen E, Detzel C, Weber T, Jose J: Autodisplay for the co-expression of lipase and foldase on the surface of $E$. coli: washing with designer bugs. Microb Cell Fact 2014, 13:19.

62. Ogino H, Inoue S, Yasuda M, Doukyu N: Hyper-activation of foldasedependent lipase with lipase-specific foldase. J Biotechnol 2013, 166:20-24.

63. Zheng $X$, Wu N, Fan Y: Characterization of a novel lipase and its specific foldase from Acinetobacter sp. XMZ-26. Process Biochem 2012, 47:643-650.

64. Park HJ, Jeon JH, Kang SG, Lee JH, Lee SA, Kim HK: Functional expression and refolding of new alkaline esterase, EM2L8 from deep-sea sediment metagenome. Protein Expr Purif 2007, 52:340-347.

65. Kwoun Kim H, Jung YJ, Choi WC, Ryu HS, Oh TK, Lee JK: Sequence-based approach to finding functional lipases from microbial genome databases. FEMS Microbiol Lett 2004, 235:349-355.

66. Sangeetha R, Arulpandi I, Geetha A: Bacterial lipases as potential industrial biocatalysts: an overview. Res J Microbiol 2011, 6:1-24.

67. Madan B, Mishra P: Co-expression of the lipase and foldase of Pseudomonas aeruginosa to a functional lipase in Escherichia coli. Appl Microbiol Biotechnol 2010, 85:597-604.

68. Pauwels K, Loris R, Vandenbussche G, Ruysschaert JM, Wyns L, Van Gelder P: Crystallization and crystal manipulation of a steric chaperone in complex with its lipase substrate. Acta Crystallogr Sect F: Struct Biol Cryst Commun 2005, 61:791-795. 
69. Nardini M, Lang DA, Liebeton K, Jaeger KE, Dijkstra BW: Crystal structure of Pseudomonas aeruginosa lipase in the open conformation. The prototype for family I.1 of bacterial lipases. J Biol Chem 2000, 275:31219-31225.

70. Liu D, Schmid RD, Rusnak M: Functional expression of Candida antarctica lipase $B$ in the Escherichia coli cytoplasm-a screening system for a frequently used biocatalyst. Appl Microbiol Biotechnol 2006, 72:1024-1032.

71. Peng R, Lin J, Wei D: Co-expression of an organic solvent-tolerant lipase and its cognate foldase of Pseudomonas aeruginosa CS-2 and the application of the immobilized recombinant lipase. App/ Biochem Biotechnol 2011, 165:926-937.

72. Nini L, Sarda L, Comeau LC, Boitard E, Dubes JP, Chahinian H: Lipasecatalysed hydrolysis of short-chain substrates in solution and in emulsion: a kinetic study. Biochim Biophys Acta 2001, 1534:34-44.

73. Jaeger KE, Dijkstra BW, Reetz MT: Bacterial biocatalysts: molecular biology, three-dimensional structures, and biotechnological applications of lipases. Annu Rev Microbiol 1999, 53:315-351.

74. Jaeger KE, Ransac S, Dijkstra BW, Colson C, van Heuvel M, Misset O: Bacterial lipases. FEMS Microbiol Rev 1994, 15:29-63.

75. JunGang L, KeGui Z, WenJun $\mathrm{H}$ : Cloning and biochemical characterization of a novel lipolytic gene from activated sludge metagenome, and its gene product. Microb Cell Fact 2010, 9:83.

76. Chu X, He H, Guo C, Sun B: Identification of two novel esterases from a marine metagenomic library derived from South China Sea. Appl Microbiol Biotechnol 2008, 80:615-625.

77. Tirawongsaroj P, Sriprang R, Harnpicharnchai P, Thongaram T, Champreda V, Tanapongpipat S, Pootanakit K, Eurwilaichitr L: Novel thermophilic and thermostable lipolytic enzymes from a Thailand hot spring metagenomic library. J Biotechnol 2008, 133:42-49.

78. Kim YJ, Choi GS, Kim SB, Yoon GS, Kim YS, Ryu YW: Screening and characterization of a novel esterase from a metagenomic library. Protein Expr Purif 2006, 45:315-323.

79. Velu N, Divakar K, Nandhinidevi G, Gautam P: Lipase from Aeromonas caviae AU04: Isolation, purification and protein aggregation. Biocatal Agric Biotechnol 2012, 1:45-50.

80. Lotrakul P, Dharmsthiti S: Purification and characterization of lipase from Aeromonas sobria LP004. J Biotechnol 1997, 54:113-120.

81. Neelambari V, Vasanthabharathi V, Balasubramanian R, Jayalakshmi S: Lipase from Marine Aeromonas hydrophila. Res J Microbiol 2011, 6:658-668.

82. Lee HK, Ahn MJ, Kwak SH, Song WH, Jeong BC: Purification and characterization of cold active lipase from psychrotrophic Aeromonas $s p$. LPB 4. J Microbiol 2003, 41:22-27.

83. Sambrook J, Maniatis T, Fritsch EF: Molecular Cloning: A Laboratory Manual. 2nd edition. : 1989.

84. Wheeler DL, Barrett T, Benson DA, Bryant SH, Canese K, Chetvernin V, Church DM, Dicuccio M, Edgar R, Federhen S, Feolo M, Geer LY, Helmberg W, Kapustin Y, Khovayko O, Landsman D, Lipman DJ, Madden TL, Maglott DR, Miller V, Ostell J, Pruitt KD, Schuler GD, Shumway M, Sequeira E, Sherry ST, Sirotkin K, Souvorov A, Starchenko G, Tatusov RL, et al: Database resources of the national center for biotechnology information. Nucleic Acids Res 2008, 36:D13-D21.

85. Krogh A, Larsson B, von Heijne G, Sonnhammer EL: Predicting transmembrane protein topology with a hidden Markov model: application to complete genomes. J Mol Biol 2001, 305:567-580.

86. Laemmli UK: Cleavage of structural proteins during the assembly of the head of bacteriophage T4. Nature 1970, 227:680-685.

87. Stuer W, Jaeger KE, Winkler UK: Purification of extracellular lipase from Pseudomonas aeruginosa. J Bacteriol 1986, 168:1070-1074.

88. Bradford MM: A rapid and sensitive method for the quantitation of microgram quantities of protein utilizing the principle of protein-dye binding. Anal Biochem 1976, 72:248-254.

89. Westermeier R, Naven T: Proteomics in Practice: A Laboratory Manual of Proteome Analysis; 2002.

90. Altschul SF, Madden TL, Schaffer AA, Zhang J, Zhang Z, Miller W, Lipman DJ: Gapped BLAST and PSI-BLAST: a new generation of protein database search programs. Nucleic Acids Res 1997, 25:3389-3402.
91. Thompson JD, Higgins DG, Gibson TJ: CLUSTAL W: improving the sensitivity of progressive multiple sequence alignment through sequence weighting, position-specific gap penalties and weight matrix choice. Nucleic Acids Res 1994, 22:4673-4680.

92. Kabsch W, Sander C: Dictionary of protein secondary structure: pattern recognition of hydrogen-bonded and geometrical features. Biopolymers 1983, 22:2577-2637.

93. Cole C, Barber JD, Barton GJ: The Jpred 3 secondary structure prediction server. Nucleic Acids Res 2008, 36:W197-W201.

94. Bond CS, Schuttelkopf AW: ALINE: a WYSIWYG protein-sequence alignment editor for publication-quality alignments. Acta Crystallogr D Biol Crystallogr 2009, 65:510-512.

95. Eswar N, Webb B, Marti-Renom MA, Madhusudhan MS, Eramian D, Shen MY, Pieper U, Sali A: Comparative protein structure modeling using Modeller. Curr Protoc Bioinformatics 2006, Chapter 5:Unit 56.

96. Capriles PV, Guimaraes AC, Otto TD, Miranda AB, Dardenne LE, Degrave WM: Structural modelling and comparative analysis of homologous, analogous and specific proteins from Trypanosoma cruzi versus Homo sapiens: putative drug targets for Chagas' disease treatment. BMC Genomics 2010, 11:610.

97. Shatsky M, Nussinov R, Wolfson H: MultiProt - A Multiple Protein Structural Alignment Algorithm. In Algorithms in Bioinformatics, Volume 2452. Edited by Guigó R, Gusfield D. Berlin Heidelberg: Springer; 2002:235-250. Lecture Notes in Computer Science.

98. Notredame C, Higgins DG, Heringa J: T-coffee: a novel method for fast and accurate multiple sequence alignment. J Mol Biol 2000, 302:205-217.

99. Laskowski RA, MacArthur MW, Moss DS, Thornton JM: PROCHECK: a program to check the stereochemical quality of protein structures. J Appl Crystallogr 1993, 26:283-291.

100. Hooft RW, Vriend G, Sander C, Abola EE: Errors in protein structures. Nature 1996, 381:272.

101. Shen $M-y$, Sali A: Statistical potential for assessment and prediction of protein structures. Protein Sci 2006, 15:2507-2524

102. Melo F, Sanchez R, Sali A: Statistical potentials for fold assessment. Protein Sci 2002, 11:430-448.

\section{Submit your next manuscript to BioMed Central and take full advantage of:}

- Convenient online submission

- Thorough peer review

- No space constraints or color figure charges

- Immediate publication on acceptance

- Inclusion in PubMed, CAS, Scopus and Google Scholar

- Research which is freely available for redistribution

Submit your manuscript at www.biomedcentral.com/submit
C Biomed Central 